\title{
Influence of Organic and Inorganic Amendments on Phosphorus Dynamics in Relation to Growth and Yield of Rice (cv. Shatabdi) in an Alfisol Soil
}

\author{
Arbind Kumar Gupta*, P.K. Patra, S.K. Ghosh and Luxmikant Tripathi \\ Department of Agricultural Chemistry and Soil Science, Bidhan Chandra Krishi \\ Viswavidhyalaya, Mohanpur -741252, Nadia, West Bengal, India \\ *Corresponding author
}

\begin{abstract}
A B S T R A C T
An experiment was conducted during 2015 rabi season in a green house, Faculty

Keywords

Available phosphorus, Phosphate solubilizing bacteria, Organic manure.

Article Info

Accepted:

21 June 2017

Available Online:

10 July 2017

of Agriculture, BCKV, Mohanpur, West Bengal to evaluate the influence of organic and inorganic amendments on phosphorus dynamics in relation to growth and yield of rice (cv. Shatabdi) in an Alfisol soil. Rhizosphere soil samples collected from pots during tillering, flowering and harvesting stages of rice were analyzed for available phosphorus. Six different treatments with and without phosphate solubilizing bacteria were tried in completely randomized design with 3 replications. Among the different treatments, Silicon through calcium silicate + Organic manure through FYM $\left(\mathrm{T}_{5}\right)$ resulted in higher values of yield attributes, (no of tillers, panicle, and plant height) and grain yield and straw yield significantly. Phosphate solubilizing bacteria inoculation showed a significantly increase in the values of yield attributes of rice and gave higher grain yield than the uninoculated ones. Interaction between different treatment and PSB showed a significant effect on the available phosphorus in soil at different stages of rice growth and yield attributes.
\end{abstract}

\section{Introduction}

Plant availability of inorganic $\mathrm{P}$ in Alfisols in the tropics can be limited by its adsorption onto $\mathrm{Fe}$ and $\mathrm{Al}$ oxides and by formation of $\mathrm{Fe}$ and Al phosphate complexes with humic acids (Gerke, 1992). Phosphorus transformation in soils involves complex microbiological, chemical and biological process. The slow mobility of applied phosphorus and its marked fixation results in low crop recoveries to the order of $20-25 \%$, which call for ways and means for its judicious use. Though, the direct application of phosphorus to rice crop seems to be one of the management option to sustain productivity, there is need to explore other factors like sources of available phosphorus, its solubilizing ability etc. to economise phosphorus use in rice production. Microbial decomposition of organic matter produces organic acids which either replace $\mathrm{P}$ sorbed on metal hydroxides or bring about dissolution of $\mathrm{P}$ locked in metal oxides by forming complexes with iron and aluminium (Hue et al., 1986). To improve the efficiency of $\mathrm{P}$ application, to sustain crop productivity, restore soil health and also to meet a part of 
chemical fertilizer requirement, it is imperative to maximize the recycling of $P$ from crop residues and organic and mineral fertilizers (Hegde and Dwivedi, 1993).

Hence, the present investigation was taken up to study the Influence of organic and inorganic amendments on phosphorus dynamics in relation to growth and yield of rice (cv. Shatabdi) in an Alfisol soil.

\section{Materials and Methods}

The Green house experiment was conducted in the department of Agricultural Chemistry and Soil Science, Faculty of Agriculture BCKV, Nadia, W.B. during Rabi season in 2015 in an Alfisol soil. The soil was typical lateritic soil (Typic Haplustalf) growing rice with good drainage facilities and texturally classified as sandy loam.

There were 3 replications of each of the following six treatments (36 pots) with or without application of a consortium of phosphate solubilising bacteria (Pseudomonas spp.) viz $\mathrm{T}_{1}=$ Control (without any amendments); $\mathrm{T}_{2}=$ Silicon @ $25 \mathrm{mg} \mathrm{kg}^{-1}$ through calcium silicate $\left[50 \mathrm{~kg} \mathrm{ha}^{-1}\right] ; \mathrm{T}_{3}=$ Silicon@25 mg ha ${ }^{-1}$ through rice straw [50 $\mathrm{kg} \mathrm{ha}{ }^{-1}$ ]; $\mathrm{T}_{4}=$ Organic manure @ $3.75 \mathrm{~g} \mathrm{~kg}$ through FYM [7.5 t ha ${ }^{-1}$ ]; $\mathrm{T}_{5}=$ Silicon@25 $\mathrm{mg} \mathrm{kg}^{-1}$ through calcium silicate [50 kg ha ${ }^{-1}$ ] +Organic manure @3.75 g kg through FYM [7.5 $\left.\mathrm{t} \mathrm{ha}^{-1}\right] ; \mathrm{T}_{6}=$ Silicon @ $25 \mathrm{mg} \mathrm{ha}^{-1}$ through rice straw $\left[50 \mathrm{~kg} \mathrm{ha}^{-1}\right]+$ Organic manure@3.75 g kg through FYM [7.5 t ha ${ }^{-1}$.

Fully decomposed FYM and silicon (through chopped rice straw) incorporated into the pots at the time of soil filling. Common dose of Nitrogen (100 kg ha ${ }^{-1}$ ) Phosphorus (50 kg ha ${ }^{-1}$ ) and Potassium (50 kg ha ${ }^{-1}$ ) were applied to all pots through Urea, DAP and MOP, respectively. While one half of fertilizer $\mathrm{N}$, full doses of $\mathrm{P}$ and $\mathrm{K}$ was applied as basal the other one half was applied at 21 days after transplanting of seedlings.

Rice variety Shatabdi was grown to maturity following standard cultural practices. Soil and plant samples were collected from the pots at the time of maximum tillering (30 DAT), booting or flowering (60 DAT) and harvesting stages (90 DAT) by following standard technique (Katznelson et al., 1948).

The bulk surface soil $(0-15 \mathrm{~cm})$ collected from rice growing low land field from Jhargram in the Red and Laterite Zone of West Bengal. Six kg air dried soil was filled in plastic pots (capacity $10 \mathrm{~kg}$ ) and saturated with water for 21 days.

Four seedlings were transplanted in each pot and thinned to two plants per pot after panicle stage. Pots were irrigated with water as and when required. Biological parameter i.e. plant height, number of tillers and number of panicles were recorded during harvesting stage of the crop.

Grain yield and straw yield were recorded at harvesting stage after proper drying. The soil samples were collected at three critical rice growth stages viz., tillering, flowering and maturity and analyzed for available phosphorus by Olsen method (1954).

The collected soil samples from pots were air dried, ground, passed through a $2 \mathrm{~mm}$ sieve and stored temporarily in polyethylene bags. The experimental soil was a sandy loam having sand $-68.16 \%$, silt- $12.00 \%$ and clay$19.84 \%$ (Bouyoucous, 1962) with acidic reaction (pH- 5.23) (Jackson, 1973); low organic carbon content $(0.42 \%)$ (Walkley and Black, 1934); medium available nitrogen (290 $\mathrm{kgha}^{-1}$ ) Subbiah and Asija (1956); low available potassium (ammonium acetate extractable) (100 $\left.\mathrm{kgha}^{-1}\right)$ (Jackson, 1973) and high available P (34.24 $\left.\mathrm{kgha}^{-1}\right)$ (Olsen, et al., 
1954). The data generated were analyzed following standard statistical methods meant for completely randomized design.

\section{Results and Discussion}

\section{Available phosphorus}

The changes in the available phosphorus content of the rhizosphere soil under different amendments during the three rice growth periods are presented table 1 and figure 1 .

In all the pots substantial increase $(\mathrm{P}<0.05)$ in available $\mathrm{P}$ from initial value $34.24 \mathrm{kgha}^{-1}$ of soil was observed.

The available phosphorus content of soil was initially higher and decreased thereafter. In all the treatments, the available $\mathrm{P}$ content was higher in $\mathrm{T}_{5}$ at tillering stage (53.89), $\mathrm{T}_{6}$ in flowering and harvesting stage (50.36 and 43.19 respectively). All the experimental pots, whether treated with organic residues $\left(T_{3}, T_{4}\right.$, $\mathrm{T}_{6}$ ) or with chemical amendments $\left(\mathrm{T}_{2}\right)$, or in combination of chemical and organic amendments $\left(\mathrm{T}_{5}\right)$ maintained higher level of available $\mathrm{P}$ as compared to the control $\left(\mathrm{T}_{1}\right)$ pots.

Initial increase in available phosphorus content of soil could be due to applied inorganic amendments, priming effect of applied inorganic $\mathrm{P}$, mineralization of organic phosphorus in the organic manure (FYM) as well as native soil organic phosphorus (Singh, et al., 2006; Laxminarayan and Patiram, 2006).

The undecomposed organic residues $\left(\mathrm{T}_{3}, \mathrm{~T}_{4}\right)$ though proved to be better than control $\left(\mathrm{T}_{1}\right)$, they were less effective in furnishing available $\mathrm{P}$ in the soil than combined application of inorganic amendments and organic manure (FYM).
The decreasing trend in available $\mathrm{P}$ content in the soil beyond tillering stage was due to transformation of available $\mathrm{P}$ into unavailable $\mathrm{P}$ pool due to resorption by clay minerals and hydrous oxide of $\mathrm{Fe}$ in the anaerobic zone (Ponnamperuma, 1985).

The available phosphorus content in the soil at different stages of plant growth was also observed in the treatments supplemented with phosphate solubilizing bacteria (Figure 2).

Compared to control, the \% increase in available phosphorus content in the soil at tillering, flowering and at harvesting stage with PSB were 8.02, 14.19 and 18.68, respectively.

Inoculation of Phosphate solubilizing bacteria play a key role in organic $\mathrm{P}$ transformation through excretion of phosphatase and phytase enzymes, enhanced mineralization of $\mathrm{P}$ from organic sources. Similar observations were reported by Laxminarayan and Patiram (2006) and Lal (2002).

\section{Growth parameter and yields}

The significant increase in different plant growth parameters viz., the no of tiller and number of panicles per hill; plant height at harvest $(\mathrm{cm})$, grain and straw yield $\left(\right.$ g.pot $\left.^{-1}\right)$ are presented in table 2 .

Grain yield and straw yield recorded after harvest of rice under different treatments ranged from 7.80 to $13.74 \mathrm{~g} \mathrm{pot}^{-1}$ and 4.85 to $7.17 \mathrm{~g} \mathrm{pot}^{-1}$. While control treatment $\left(\mathrm{T}_{1}\right)$ effectuated the lowest grain yield and application of Silicon@ $25 \mathrm{mg} \mathrm{kg}^{-1}$ through calcium silicate and Organic manure @ $3.75 \mathrm{~g}$ kg through FYM (T5) produced the highest. Statistical analysis of data and comparison of treatment means revealed, that T5 produced maximum no of tillers (9), panicles (8) and plant height $(116.0 \mathrm{~cm})$. 
Table.1 Effect of sole and combined application of silicon and FYM on available Phosphorus content of the soil at different stages of plant growth of rice crop

\begin{tabular}{|c|c|c|c|}
\hline \multirow[b]{2}{*}{ Treatments } & \multicolumn{3}{|c|}{$\begin{array}{l}\text { Available P Content of Soil at Different Stages of Plant Growth of rice } \\
\qquad \begin{array}{c}\operatorname{crop}\left(\mathrm{kgha}^{-1}\right)\end{array}\end{array}$} \\
\hline & Tillering stage & Flowering stage & Harvesting stage \\
\hline T1 & 34.75 & 29.82 & 14.13 \\
\hline $\mathbf{T} 2$ & 40.75 & 32.22 & 17.34 \\
\hline T3 & 41.89 & 31.94 & 19.69 \\
\hline $\mathbf{T 4}$ & 52.19 & 42.40 & 27.81 \\
\hline T5 & 53.89 & 45.93 & 39.04 \\
\hline T6 & 53.25 & 50.36 & 43.19 \\
\hline Mean & 46.12 & 38.78 & 26.87 \\
\hline Initial & \multicolumn{3}{|c|}{34.24} \\
\hline $\operatorname{SEm}( \pm)$ & 1.34 & 1.06 & 1.92 \\
\hline CD (0.05) & 3.90 & 3.09 & 5.60 \\
\hline \multicolumn{4}{|c|}{ PSB } \\
\hline Without & 44.34 & 36.21 & 24.57 \\
\hline With & 47.90 & 41.35 & 29.16 \\
\hline Mean & 46.12 & 38.78 & 26.87 \\
\hline $\operatorname{SEm}( \pm)$ & 0.77 & 0.61 & 1.11 \\
\hline CD (0.05) & 2.25 & 1.78 & 3.23 \\
\hline
\end{tabular}

Table.2 Effect of sole and combined application of silicon and FYM on different growth parameters of rice crop

\begin{tabular}{|c|c|c|c|c|c|}
\hline \multicolumn{6}{|c|}{ Different Plant Growth Parameters } \\
\hline Treatments & $\begin{array}{c}\text { Tillers } \\
\left(\text { no.Hill }^{-1}\right)\end{array}$ & $\begin{array}{c}\text { Panicle } \\
\left(\text { no.Hill }^{-1}\right)\end{array}$ & Height (cm) & $\begin{array}{c}\text { Grain Yield } \\
\left(\text { g.pot }^{-1}\right)\end{array}$ & $\begin{array}{c}\text { Straw Yield } \\
(\text { g.pot }\end{array}$ \\
\hline T1 & 7 & 6 & 100 & 7.80 & 5.71 \\
\hline $\mathbf{T 2}$ & 8 & 7 & 103 & 8.70 & 6.19 \\
\hline T3 & 8 & 8 & 108 & 8.47 & 4.85 \\
\hline T4 & 8 & 8 & 110 & 12.74 & 5.55 \\
\hline T5 & 9 & 8 & 116 & 13.74 & 7.17 \\
\hline T6 & 8 & 7 & 109 & 12.02 & 5.59 \\
\hline Mean & 8 & 7 & $\mathbf{1 0 7 . 5 4}$ & 10.58 & 5.84 \\
\hline $\operatorname{SEm}( \pm)$ & 0.30 & 0.35 & 2.78 & 0.33 & 0.61 \\
\hline CD (0.05) & 0.87 & 1.03 & 8.11 & 0.98 & 1.77 \\
\hline \multicolumn{6}{|c|}{ PSB } \\
\hline Without & 8 & 7 & 106 & 10.10 & 5.27 \\
\hline With & 8 & 8 & 109 & 11.05 & 6.41 \\
\hline Mean & 8 & 7 & 108 & 10.58 & 5.84 \\
\hline $\operatorname{SEm}( \pm)$ & 0.17 & 0.20 & 1.60 & 0.19 & 0.35 \\
\hline CD (0.05) & 0.50 & 0.60 & 4.68 & 0.56 & 1.02 \\
\hline
\end{tabular}


Table.3 Interaction effect of treatments and PSB on available P content of soil and different growth parameters of rice crop

\begin{tabular}{|c|c|c|c|c|c|c|c|c|}
\hline \multicolumn{4}{|c|}{$\begin{array}{c}\text { Available P Content of Soil at Different Stages of Plant } \\
\text { Growth of rice crop }\left(\mathrm{kgha}^{-1}\right)\end{array}$} & \multicolumn{5}{|c|}{ Different Plant Growth Parameters } \\
\hline $\begin{array}{l}\text { Treatments } \\
\text { x PSB }\end{array}$ & $\begin{array}{c}\text { Tillering } \\
\text { stage }\end{array}$ & $\begin{array}{c}\text { Flowering } \\
\text { stage }\end{array}$ & $\begin{array}{c}\text { Harvesting } \\
\text { stage }\end{array}$ & $\begin{array}{c}\text { Tillers } \\
(\text { no.Hill } \\
\text { (1) }\end{array}$ & $\begin{array}{c}\text { Panicle } \\
(\text { no.Hill } \\
\text { (1) }\end{array}$ & $\begin{array}{c}\text { Height } \\
(\mathrm{cm})\end{array}$ & $\begin{array}{c}\text { Grain } \\
\text { Yield } \\
\left(\text { g.pot }^{-1}\right)\end{array}$ & $\begin{array}{c}\text { Straw } \\
\text { Yield } \\
\left(\text { g.pot }^{-1}\right)\end{array}$ \\
\hline $\mathbf{T}_{1} \times \mathbf{P S B}_{0}$ & 30.48 & 27.19 & 11.55 & 6 & 6 & 98 & 7.30 & 4.85 \\
\hline $\mathbf{T}_{1} \mathbf{x P S B}_{1}$ & 39.02 & 32.46 & 16.71 & 7 & 6 & 102 & 8.30 & 6.56 \\
\hline $\mathbf{T}_{2} \times P_{S B}$ & 39.07 & 30.68 & 16.31 & 8 & 7 & 103 & 7.70 & 6.93 \\
\hline $\mathbf{T}_{2} \times \mathbf{P S B}_{1}$ & 42.43 & 33.75 & 18.36 & 8 & 7 & 104 & 9.70 & 5.44 \\
\hline $\mathbf{T}_{3} \times \mathbf{P S B}_{0}$ & 40.83 & 30.63 & 19.53 & 7 & 7 & 106 & 8.37 & 4.32 \\
\hline $\mathbf{T}_{3} \times P B_{1}$ & 42.94 & 33.26 & 19.86 & 9 & 8 & 110 & 8.57 & 5.37 \\
\hline $\mathbf{T}_{4} \times \mathbf{P S B}_{0}$ & 51.32 & 39.92 & 27.21 & 8 & 7 & 108 & 12.59 & 4.58 \\
\hline $\mathbf{T}_{4} \times \mathbf{P S B}_{1}$ & 53.05 & 44.89 & 28.40 & 8 & 8 & 111 & 12.88 & 6.52 \\
\hline $\mathbf{T}_{5} \times P B_{0}$ & 53.03 & 40.53 & 36.27 & 8 & 7 & 114 & 13.15 & 6.38 \\
\hline $\mathrm{T}_{5} \mathrm{xPSB}_{1}$ & 54.75 & 51.32 & 41.82 & 10 & 9 & 117 & 14.34 & 7.97 \\
\hline $\mathbf{T}_{6} \times \mathbf{P S B}_{0}$ & 51.32 & 48.31 & 36.56 & 7 & 7 & 109 & 11.51 & 4.57 \\
\hline $\mathbf{T}_{6} x P B_{1}$ & 55.18 & 52.41 & 49.83 & 8 & 7 & 109 & 12.53 & 6.60 \\
\hline Mean & 46.12 & 38.78 & 26.87 & 8 & 7 & 107.54 & 10.58 & 5.84 \\
\hline $\operatorname{SEm}( \pm)$ & 1.89 & 1.50 & 2.71 & 0.42 & 0.50 & 3.93 & 0.47 & 0.86 \\
\hline CD (0.05) & 5.52 & 4.37 & 7.92 & 1.22 & 1.46 & 11.46 & 1.38 & 2.50 \\
\hline
\end{tabular}

$\mathrm{PSB}_{0}=$ Without PSB $; \mathrm{PSB}_{1}=$ With PSB 
Fig.1 Effect of sole and combined application of silicon and FYM on available Phosphorus content of the soil at different stages of plant growth of rice crop

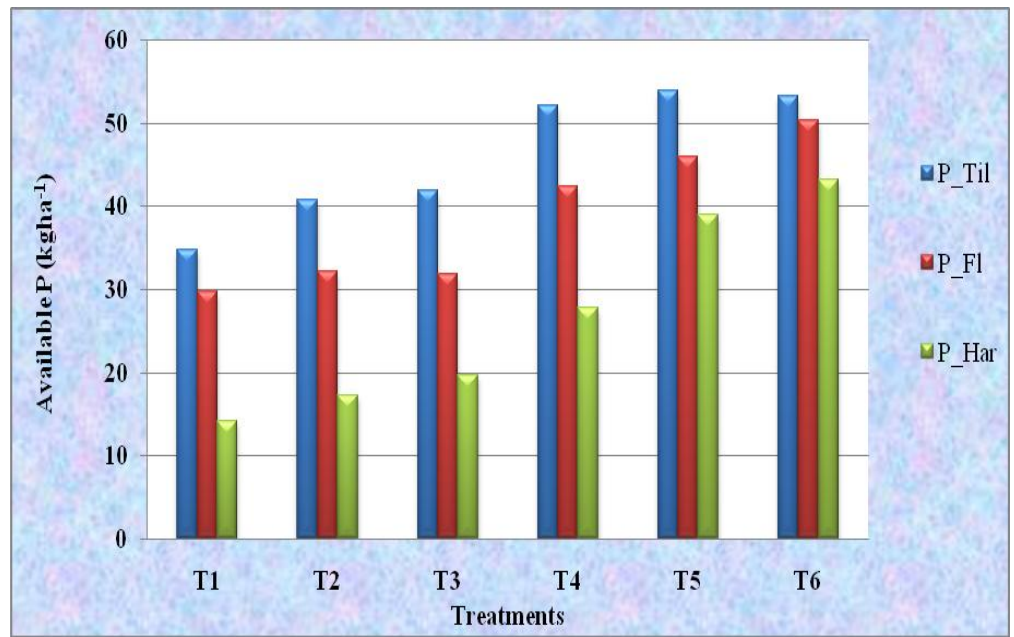

Fig.2 Effect of PSB on available phosphorus content of the soil at different stages of plant growth of rice crop

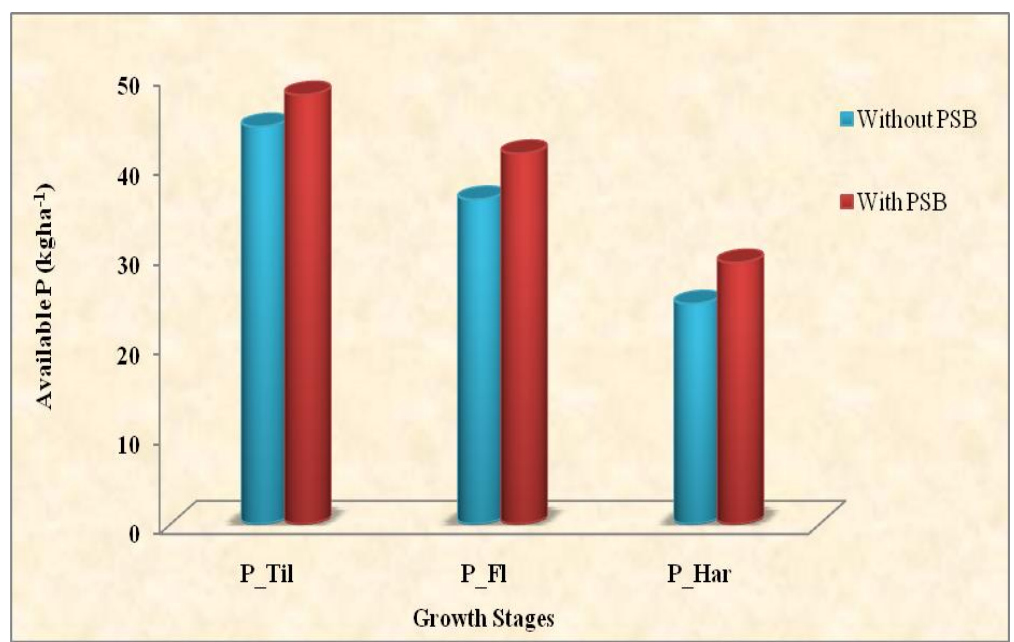

The inoculation of phosphate solubilizing bacteria had a significant effect in all the yield attributing characters of rice. Phosphate solubilizing bacteria synthesized growth promoting substances and produced vitamins, which augmented the root growth and resulted in better nutrient uptake. Not only this, phosphate solubilizing bacteria inoculation enhanced the mineralization of organic forms of phosphorus and solubilization of inorganic phosphorus, improving the availability of native soil phosphorus to plants and thereby increased yield attributes resulting to higher grain yield. Similar observations were opined by Lal (2002).

\section{Interaction effect}

The interaction between different treatment and PSB showed a significant effect on the available phosphorus in soil at different stages of rice growth (Table 3). The best combination was found to be silicon through 
rice straw + organic manure through FYM + PSB $\left(\mathrm{T}_{6}\right)$ during all growth stages (Tillering, flowering, harvesting) of rice. Application of PSB along with treatments in general resulted higher increment in the available phosphorus content of the soil at different stages of plant growth.

The significant result also showed on yield and yield attributes viz., no of tillers, no of panicles, plant height and the best combination was found to be silicon through calcium silicate + organic manure through $\mathrm{FYM}+\mathrm{PSB}\left(\mathrm{T}_{5}\right)$.

\section{References}

Bouyoucos, G. J. 1962. Hydrometer method for making particle size analysis at soils. Agronomy Journal, 54: 36-46.

Gerke, J. 1992.Orthophosphate and organic phosphate in the soil solution of four sandy soils in relation to $\mathrm{pH}$ : evidence for humic- Fe (Al) phosphate complexs. Soil Sci Pl Ana, 23: 601- 12.

Hegde, D.M and Dwivedi, B.S. 1993.Integrated nutrient management for dry land agriculture. Fert. News, 39:19-26.

Hue, N. V., Craddock, G. R and Adams, F. 1986.Effect of organic acids on aluminium toxicity in sub soils. Soil Sci. Soc. America J., 50:28-34.

Jackson, M.L. 1973. Soil Chemical Analysis. Prentice Hall of India Pvt. Ltd. New Delhi.

Katznelson, H., Lochhead, A.R and Timinin, M.L. 1948.Soil microorganisms and the rhizosphere. Bot. Rev., 14: 543-87.

Lal, L. 2002. Phospahtic Biofertilizer. Published by Agrotech Publishing Academy, Udaipur.

Laxminarayana, K and Patiram. 2006. Effect of integrated use of inorganic, biological and organic manures on rice productivity and soil fertility in Ultisol of Mizoram. Journal of the Indian Society of Soil Science, 54:213-20.

Olsen, S. R., Cole, C. V., Watanabe, F. S and Dean, L. A. 1954. Estimation of available phosphorus in soils by extraction with sodium bicarbonate. United States Department of Agriculture Circular, 19: 939

Ponnamperuma, F. N. 1985. Chemical kinetics of wetland rice soils relative to soil fertility. In Wetland Soils: Characterization, Classification and Utilization, Int. Nat. Res. Inst., Los Banos, Laguna, Philippines, pp: 71-89.1

Singh, V., Dhillon, N.S and Brar, B.S. 2006. Effect of incorporation of crop residues and organic manures on adsorption/desorption and bioavailability of phosphate. Nutr. Cycl. Agroecosyst, 76:95-108.

Subbiah, B.V and Asija, G.L. 1956. A rapid procedure for the estimation of available nitrogen in soils. Current Science, 25: 259-260.

Walkley, A. and Black, I. A. 1934. An examination of the Degtjareff method for determining soil organic matter, and a proposed modification of the chromic acid titration method. Soil Science, 34: 29-38.

\section{How to cite this article:}

Arbind Kumar Gupta, P.K. Patra, S.K. Ghosh and Luxmikant Tripathi. 2017. Influence of Organic and Inorganic Amendments on Phosphorus Dynamics in Relation to Growth and Yield of Rice (cv. Shatabdi) in an Alfisol Soil. Int.J.Curr.Microbiol.App.Sci. 6(7): 1982-1988. doi: https://doi.org/10.20546/ijcmas.2017.607.235 